\title{
Discrimination Among Youth of Immigrant Descent in Germany
}

\section{Do School and Cultural Belonging Weaken Links to Negative Socioemotional and Academic Adjustment?}

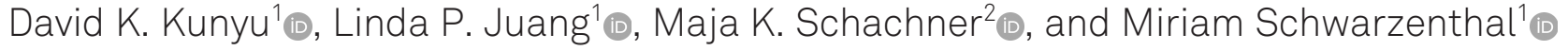 \\ ${ }^{1}$ Inclusive Education, University of Potsdam, Germany \\ ²Educational Psychology, Martin Luther University of Halle-Wittenberg, Germany
}

\begin{abstract}
Ethnic discrimination has a negative impact on the socioemotional, behavioral, relational, and academic adjustment of adolescents, while belonging with classmates, teachers, heritage, and national group may promote positive socioemotional and academic adjustment. We investigate (1) whether greater discrimination by peers and a lower sense of belonging with classmates, teachers, heritage group, and national group are associated with lower socioemotional and academic adjustment of adolescents of immigrant descent in Germany; and (2) whether a sense of belonging with these different sources acts as a protective factor lowering the negative effects of discrimination on adjustment. Our sample included 439 7th-grade adolescents ( $51 \%$ female, $M_{a g e}=12.4$ years) of immigrant descent from 15 Berlin secondary schools. Results showed that higher discrimination was related to greater physiological stress, depressive symptoms, and disruptive school behavior. Higher heritage (but not national) identity, a higher sense of belonging with classmates and with teachers were associated with better socioemotional and academic adjustment. An examination of interaction effects between discrimination and forms of belonging on adjustment revealed that, while the association between discrimination and poorer adjustment weakened for those with higher heritage identity, the association between discrimination and physiological stress increased for those with higher teacher relatedness. We conclude that heritage identity (but not national identity or sense of belonging with classmates) can indeed be a protective factor against the negative effects of discrimination for adolescents of immigrant descent in Germany. Even though belonging with teachers may exacerbate discrimination effects, further investigation with longitudinal data is needed. The findings underline the important role of heritage ties among adolescents of immigrant descent as a source of adjustment, especially in light of discrimination experiences.
\end{abstract}

Keywords: discrimination, sense of belonging, identity, immigrant descent adolescents, adjustment

Diskriminierung von Jugendlichen mit Zuwanderungsgeschichte in Deutschland: Vermindern Schulzugehörigkeit und kulturelle Zugehörigkeit den Zusammenhang mit negativer sozio-emotionaler und akademischer Anpassung?

Zusammenfassung: Während ethnische Diskriminierung einen negativen Effekt auf die sozio-emotionale, verhaltensbezogene, relationale und akademische Anpassung von Jugendlichen hat, fördert die Zugehörigkeit zu Mitschüler*innen, Lehrkräften sowie der Herkunfts- und nationalen Gruppe sozio-emotionale und akademische Anpassung. Es wurde untersucht (1) ob höhere Diskriminierung und ein geringeres Zugehörigkeitsgefühl mit Mitschüler*innen, Lehrkräften, Herkunfts- und nationaler Gruppe mit geringerer sozio-emotionaler und akademischer Anpassung von Jugendlichen mit Zuwanderungsgeschichte in Deutschland zusammenhängen, und (2) ob das Zugehörigkeitsgefühl auf diesen verschiedenen Ebenen als Schutzfaktor wirkt, der die negativen Effekte von Diskriminierung abmildern kann. Unsere Analyse beruht auf Selbstberichtsdaten von 439 Jugendlichen mit Zuwanderungsgeschichte der Jahrgangsstufe 7 ( $51 \%$ weiblich, $M_{\text {Alter }}=12.4 \mathrm{Jahre}$ ) aus 15 Berliner Sekundarschulen. Die Ergebnisse zeigten, dass mehr Diskriminierung mit höherem physiologischem Stress, depressiven Symptomen und Störverhalten in der Schule verbunden war. Stärkere Identifikation mit der Herkunftsgruppe (nicht aber mit der nationalen Gruppe) sowie höhere Zugehörigkeitsgefühle mit Mitschüler*innen sowie mit Lehrkräften gingen mit höherer sozio-emotionaler und akademischer Anpassung einher. Die Analyse von Interaktionseffekten zwischen Diskriminierung und Aspekten der Zugehörigkeit auf Anpassung zeigte, dass sich der Zusammenhang zwischen Diskriminierung und geringerer Anpassung für diejenigen mit einer stärkeren Identifikation mit der Herkunftsgruppe abschwächte, während der Zusammenhang zwischen Diskriminierung und physiologischem Stress für diejenigen mit einer höheren Zugehörigkeit zu Lehrkräften zunahm. Wir schließen daraus, dass die Identifikation mit der Herkunftsgruppe (nicht aber die nationale Identifikation oder ein Zugehörigkeitsgefühl mit Mitschüler*innen) als Schutzfaktor gegen die negativen Effekte von Diskriminierung bei Jugendlichen mit Zuwanderungsgeschichte in Deutschland dienen kann. Ein Zugehörigkeitsgefühl mit Lehrkräften kann Diskriminierungseffekte sogar verstärken, allerdings sollte dieser Zusammenhang mit Längsschnittstudien weiter untersucht werden. Die Ergebnisse unterstreichen die wichtige Rolle der Verbundenheit mit der Herkunftsgruppe für die Anpassung von Jugendlichen mit Zuwanderungsgeschichte, insbesondere wenn Diskriminierungserfahrungen vorliegen.

Schlagwörter: Diskriminierung, Zugehörigkeitsgefühl, Identität, Jugendliche mit Zuwanderungsgeschichte, Anpassung 
Ethnic discrimination can be conceptualized as being treated unfairly or negatively, such as being excluded or harassed verbally, because of one's ethnic background (Garrett et al., 2017; Jasinskaja-Lahti et al., 2003). The negative effects of discrimination on the well-being of adolescents of immigrant descent ${ }^{1}$ are well documented (e.g., Maes et al., 2014; Reitz et al., 2015; Stein et al., 2015).

Benner and colleagues' (2018) recent meta-analysis reviewed 214 studies, published through 2016, on ethnic discrimination and well-being during adolescence. Notably, only $4 \%$ were conducted in Europe. However, experiencing ethnic discrimination is a part of everyday life among adolescents of immigrant descent in Germany and the rest of Europe (Berry et al., 2006; Frankenberg et al., 2013), and it poses adjustment threats socioemotionally (e.g., poor mental health), relationally and academically (e.g., negative behavior and poor academic achievement) (see Aichberger et al., 2015; Stein et al., 2015). Germany, with its long-standing history of immigration, in recent years has continued to record among the highest arrivals of immigrants and asylum-seekers in continental Europe (Bundesamt für Migration und Flüchtlinge, 2018). Youth of immigrant descent in Germany are of no expection from being confronted with ethnic discrimination risks (Göbel \& Preusche, 2019), but understanding the links between discrimination and adjustment and what may weaken these links remains understudied in this context.

\section{The Need to Belong Among Adolescents}

A sense of belonging is a fundamental human need necessary for good health and well-being (Baumeister \& Leary, 1995). Ryan and Deci (2017, p. 86) refer to a sense of belonging as "both experiencing others as responsive and sensitive and being able to be responsive and sensitive to them". The need is therefore satisfied bidirectionally (Deci \& Ryan, 2014). A high sense of belonging enhances more flexibility and constructive actions when confronted with challenges (Furrer \& Skinner, 2003), and may promote both psychological and physical health (Korpershoek et al., 2019) as well as positive school engagement and achievement (Schachner et al., 2019) among children and adolescents. A sense of belonging may occur at various levels: at the level of cultural group (i.e., heritage and national identity) or at the level of school (i.e., sense of belonging with classmates and teachers), and it can be an important resource specifically for immigrant and refugee youth (Juang et al., 2018). At the same time, ethnic minorities may be more sensitive about issues of belonging compared to the majority (Walton \& Cohen, 2007). Social psychological research has therefore highlighted the sense of belonging as an important mechanism that can alleviate the negative effects of stereotype threat, a more subtle form of perceived discrimination (Shnabel et al., 2013; Walton \& Cohen, 2007). Our study goes beyond previous research by exploring how a sense of belonging at different levels, from cultural group to school, can potentially buffer the negative effects of perceived discrimination amongst youth of immigrant descent in Germany.

\section{Sense of Belonging to a Cultural Group Through Heritage and National Identities}

One way to study a sense of belonging to a cultural group is through the concept of ethnic identity, "an enduring, fundamental aspect of the self that includes a sense of membership in an ethnic group and the attitudes and feelings associated with that membership" (Phinney, 1996, p. 922). During adolescence, individuals explore the meaning of ethnicity, race, and heritage culture for their identity in greater depth (Umaña-Taylor et al., 2014). Because of their increasing ability to think critically, take perspective, and expose themselves to broader contexts and relationships beyond the home, young people in their early adolescence begin to make sense of and articulate the implications of ethnicity, race, and heritage culture on their daily lives and consider how others may view their ethnic group (Benner \& Wang, 2017; Quintana, 2008). This process can trigger a sense of belonging to their ethnic group. The feeling of belonging to one's ethnic group is referred to in this study as heritage identity. We chose this term even though the term "ethnic identity" is common in literature (especially in the U.S.

\footnotetext{
The term adolescents of "immigrant descent" as used in this study means at least one parent, grandparent, or the adolescents themselves were born outside of Germany. The Federal Government Expert Commission (2021) recommended no longer using the term "migration background" to aggregate immigrant, second, and later generations, but rather "immigrants and their direct descendants." The commission also recommends that "migrant" should be replaced with "immigrant." Most of our sample are not immigrants, and in the analyses we controlled for generational status. Thus, we use "immigrant descent" to describe our sample.
} 
context). In the German context, however, discussions of cultural belonging center around heritage and immigration background rather than ethnicity and race (Vietze et al., 2019).

Individuals with a stronger heritage identity have a clearer commitment and stronger attachment to their group. Stronger heritage identity may have both promotive effects (i.e., operate in the presence of risks to minimize negative outcomes - main effects model), and protective effects (i.e., interactively modify the effects of risks - buffering model) (Zimmerman et al., 2013).

Research in Germany and elsewhere has shown that adolescents of immigrant descent with a stronger heritage identity may have better psychological outcomes and well-being (e.g., Frankenberg et al., 2013; Schachner et al., 2016; Umaña-Taylor et al., 2014). One review (RivasDrake et al., 2014) found that stronger heritage identity is directly related to higher self-esteem and well-being among different heritage groups. Interactively, adolescents with a strong sense of belonging to their heritage group in the U.S. were also less likely to be negatively affected by discrimination from their peers and they instead exhibited better adjustment socioemotionally, relationally, and academically (Greene et al., 2006; Rivas-Drake et al., 2014; for a meta-analysis, see Yip et al., 2019). From developmental and social identity perspectives (Erikson, 1968; Tajfel \& Turner, 1979), a strong heritage identity may work as a protective factor by providing the cognitive and emotional assurance and security of being part of a valued social community when faced with experiences of being devalued (Yip et al., 2019). In addition, the experience of being devalued by one group may be compensated by seeking identification with another social group, a phenomenon also referred to in social psychological research as "rejection-identification" (Branscombe et al., 1999). Our study goes beyond examining direct effects to test the potential of heritage identity to act as a protective factor, buffering the negative effects of perceived discrimination among adolescents of immigrant descent in Germany.

Besides heritage identity, national identity (i. e., feelings of belonging toward a country or nation in which one lives) may also act as a promotive factor for adolescent adjustment. Adolescents of immigrant descent with stronger national identities show better school adjustment; for instance, they tend to have higher levels of motivation and academic achievement (Berry et al, 2006). Adolescents of immigrant descent in Germany with stronger national identities also report greater motivation, engagement, and achievement in school, whereas findings were inconclusive concerning a direct association with psychological well-being (Göbel \& Preusche, 2019; Schachner et al., 2016; Schotte et al., 2018).
Whether national identity serves as protective factor is unclear in the literature. On the one hand, like heritage identity, a stronger national identity could potentially act as a protective factor by providing the assurance and security of being part of a valued social community in the face of discrimination (Yip et al., 2019). On the other hand, in line with identity-denial research, those with stronger national identities would not be protected but would in fact be more vulnerable to the negative effects of discrimination because they experience exclusion from the larger community they seek to identify with. A study on identity denial (i.e., a form of discrimination where one's self-chosen identity such as being American is disputed by others) among Asian Americans showed that those who were born and raised in the U.S. (second and later generation) reported having stronger negative emotions when experiencing identity denial compared to those who had immigrated themselves (first generation) (Wang et al., 2012). And among the first generation, those who identified more strongly with being American also reported more negative emotions when experiencing identity denial (Wang et al., 2012). Because of inconsistent evidence, our test for the potential buffering effects of national identity among German adolescents of immigrant descent is exploratory.

\section{Belonging with Classmates and with Teachers}

In school contexts, belonging is pivotal for successful academic and socioemotional adjustment (Golaszewski et al., 2018; Slaten et al., 2016). School belonging refers to a student's perception and experience of safety, connectedness, and teacher fairness and support at school (Libbey, 2004). It encompasses the students' emotions concerning their being important and respected members (Booker, 2004) and their inclusion (Goodenow \& Grady, 1993) in the school community. Students who exhibit a greater sense of belonging engage more productively and cope positively with daily stressors (Kelly et al., 2018).

A high sense of belonging with classmates and teachers was directly linked not only to an adolescent's positive academic adjustment, self-esteem, and better physical health (Kiang, Supple, Stein, \& Gonzalez, 2011; Schachner et al., 2019), but also to lower levels of disruptive behavior (Loukas et al., 2008). Especially for immigrant adolescents, relationships at school play a central role in promoting socially competent behavior in the classroom and the school environment, and in fostering academic 
engagement and achievement (Suarez-Orozco et al., 2009).

In contrast, lower school belonging is directly linked to negative outcomes, such as school dropout, poorer grades, and poorer health (Brenick et al., 2018; Fernandez, et al., 2019; Verkuyten et al., 2019). Brenick and colleagues found that higher perceived ethnic discrimination (which would lower perceived school belonging) among Turkish-heritage early adolescents in Germany was related to their conduct problems and depressive symptoms.

Besides these direct associations playing a promotive role, school belonging was also linked to playing a buffering role. Reaffirming a sense of belonging through writing can buffer the negative effects of stereotype threat (a form of perceived discrimination) on the adjustment of ethnic minority adolescents (e.g., Shnabel et al., 2013; Walton, \& Cohen, 2007). A sense of belonging with teachers could also potentially buffer the negative effects of discrimination, as students who believe their teacher will not ignore discrimination when it happens feel safer in the classroom (Verkuyten \& Thijs, 2002). The current study adds to the existing literature by examining whether belonging with classmates and teachers can buffer the negative effects of perceived discrimination on the adjustment of adolescents of immigrant descent in Germany.

In sum, ethnic discrimination has negative effects on socioemotional and academic adjustment of immigrant descent adolescents. A sense of belonging (i.e., cultural belonging and school belonging) is important for these adolescents and may have both promotive and protective effects in the event they are faced with discrimination.

\section{The Present Study}

We examined the relationships between ethnic discrimination and sense of belonging (to heritage group, national group, classmates, and teachers) with the socioemotional and academic adjustment of adolescents of immigrant descent. The two research questions are:

1) Are higher discrimination and a lower sense of belonging with classmates, teachers, heritage group, and national group associated with lower socioemotional and academic adjustment of adolescents of immigrant descent in Germany?

2) Does a sense of belonging with these different sources (classmates, teachers, heritage group, and national group) act as a protective factor lowering the negative effects of discrimination on adjustment?

We hypothesized the following:
Hypothesis 1 (H1): Higher discrimination experiences are linked to poorer socioemotional and academic adjustment of adolescents of immigrant descent.

Hypothesis 2 (H2): A higher sense of belonging to heritage group (i.e., heritage identity - $\mathrm{H} 2 \mathrm{a}$ ), national group (i.e., German identity - H2b), with classmates $(\mathrm{H} 2 \mathrm{c})$, and with teachers $(\mathrm{H} 2 \mathrm{~d})$ is associated with higher socioemotional and academic adjustment of adolescents of immigrant descent.

Hypothesis 3 (H3): The association between higher discrimination experiences and lower socioemotional and academic adjustment is weaker for adolescents of immigrant descent with a higher sense of belonging to heritage group (i.e., heritage identity - H3a), with classmates (H3b), and with teachers (H3c).

Hypothesis 4 (H4): Because of the mixed evidence of the effect of the interaction between discrimination and sense of belonging to the national group (i. e., German identity) on socioemotional adjustment, we test this link in an exploratory fashion.

\section{Method}

\section{Participants}

A subsample from the first wave of a three-wave longitudinal intervention study on self-affirmation that was conducted with $6527^{\text {th }}$-grade adolescents was included in this study. The intervention aimed to boost protective factors, that is, a sense of belonging, autonomy, and competence, especially for adolescents of immigrant descent experiencing acculturative stress. We focused on the first wave as the adolescents had not yet undergone the intervention. The participants were drawn from 57 classrooms in 15 culturally diverse secondary schools in Berlin, Germany. To recruit schools, we mailed a written description of the study and a request to participate to 211 secondary schools in Berlin and followed up with a telephone call from four members of the research team. Of the schools contacted, the principals of 15 schools (8\%) agreed to participate (eight integrated secondary schools, three Gymnasiums, and four comprehensive schools). To test our hypotheses, we focused on 439 (67\%) adolescents of immigrant descent $\left(M_{\text {age }}=12.4\right.$ years, $S D_{\text {age }}=.73$, $51 \%$ female). $8 \%$ of the sample were first-generation immigrants (born outside of Germany and immigrated after they began school), and the rest were secondgeneration (79\%) and third-generation (10\%) immigrants. Based on self-reported heritage identity and the birthplace of their parents and grandparents, participants represented four heritage groups, namely, Turkish-herit- 
age Germans $(N=116)$, which generally represent the largest immigrant group in Germany, Arab-heritage ${ }^{2}$ Germans $(N=121)$, Eastern European ${ }^{3}$-heritage Germans $(N=$ $121)$, and Germans of other immigrant descent ${ }^{4}(N=72)$.

\section{Procedure}

We received approval from the Ethics Committee of the University of Potsdam and from the Berlin Senate Administration for Education, Youth, and Family. Students with parental consent voluntarily completed the survey during two class periods. The survey materials were available in German. Each class received a small compensation $(25 €)$ for their participation.

\section{Measures}

Reliabilities for individual scales appear in Table 1. All scales demonstrated adequate reliability for the samples. We calculated mean scores for all scales.

\section{Discrimination}

Six items measured the extent to which participants had experienced events of unfair or negative treatment by their classmates in the past year which they attributed to their ethnic background (Titzmann et al., 2011), such as "I was teased by other students because of my heritage culture." Responses were rated on a 5-point Likert- scale ( $1=$ never, $2=1$ to 2 times, $3=3$ to 5 times, $4=6$ to 10 times, and $5=$ more than 10 times).

\section{Heritage and National Identities}

We assessed heritage and national identities using the German measure of adolescents' ethnic and national identity (Leszczensky \& Gräbs Santiago, 2014), we used six items from the heritage identity subscale, such as "I feel like I am a part of my family's heritage country," and six items from the national identity subscale, such as "I feel like I am a part of Germany." Adolescents' responses were rated on a 4 -point Likert-scale $(1=$ totally disagree to $4=$ totally agree $)$.

\section{Sense of Belonging with Classmates and Teachers}

We used the Sense of Relatedness subscales for belonging with classmates and teachers (Furrer \& Skinner, 2003). Each subscale had four items, rated on a 4-point Likert scale $(1=$ totally disagree to $4=$ totally agree $)$. For belonging with classmates, a sample item is "When I'm with my classmates, I feel ignored" (reverse coded). For belonging with teachers, a sample item is "When I'm with my teacher, I feel accepted." We initially found a low internal consistency for belonging with classmates $(\alpha=$ $.63)$ and teachers $(\alpha=.54)$. The subscale items, "When I'm with my classmates, I feel like someone special" and "When I'm with my teacher, I feel like someone special" had unusually low means and low correlations with other items. We thus excluded these two items and report the improved reliabilities in Table 1.

\section{Physiological Stress and Depressive Symptoms}

To measure physiological stress and depressive symptoms we used a 5-item measure used in a multicountry study of immigrant youth (Berry et al., 2006). Sample items for physiological stress and depressive symptoms are "I feel tired" and "I feel lonely even if I'm with other people," respectively. They were rated on a 5-point Likert scale $(1=$ almost never to $5=$ very often).

\section{Disruptive School Behavior}

From Jenkins' (1995) scale on school delinquency and school commitment we drew 5 items that were considered appropriate for the age group and the German context and had proved valid and reliable in this target group in previous research (Schachner et al., 2014). The items were rated on a 5 -point Likert scale $(1=$ almost never to $5=$ very often). An example is, "How often did you refuse to do a task given by the teacher in the last four weeks?"

\section{Academic Engagement}

We used a behavioral engagement scale to assess academic engagement by asking the adolescents to report on their effort, attention, and persistence while initiating and participating in learning activities (Skinner et al., 2009). This scale has been used previously with German adolescents (see Bakadorova \& Raufelder, 2014). A sample item is, "I enjoy learning new things in school." The 10 items

\footnotetext{
2 Arab heritage includes persons from Egypt, Algeria, Iraq, Jordan, Palestine, Kuwait, Lebanon, Libya, Morocco, Mauritania, Tunisia, Chad, Qatar, Saudi Arabia, Oman, Somalia, Sudan, Syria, Bahrain, Djibouti, Eritrea, United Arab Emirates, Kurdish from Iraq, and Yemen. They share a commonality in terms of language.

3 Eastern European heritage includes persons from Russia, Lithuania, Estonia, Romania, Ukraine, Moldova, Armenia, Azerbaijan, Georgia, Czech Republic, Hungary, Slovakia, Slovenia, Republic of Macedonia, Serbia and Montenegro, Bosnia and Herzegovina, Bulgaria, Croatia, Albania, Belarus, and Poland.

4 Other heritage includes persons from Vietnam, China, Ghana, Pakistan, Iran, Afghanistan, Thailand, Philippines, India, Nepal, Kazakhstan, Uzbekistan, Japan, Australia, Togo, Senegal, Cameroon, DR Congo, Zimbabwe, Burkina Faso, Nigeria, Bolivia, Costa Rica, Brazil, Argentina, Canada, and the U.S.
} 
were rated on a 5 -point Likert scale $(1=$ totally disagree to $5=$ totally agree)

\section{Covariates}

Covariates were assessed using students' questionnaires and included age, gender, immigrant generation, heritage groups (i.e., Turkish, Arab, Eastern European, and other immigrant descent), and socioeconomic status (SES). The SES of adolescents was assessed using the Family Affluence Scale (FAS) (Boyce et al., 2006), which was validated in Germany by Richter and Leppin (2007). Four items ask about (1) whether the family has a car $(0=n o, 1=y e s$, one, or $2=y e s$, two or more); (2) whether the child has his or her own room at home $(0=n o$ or $1=y e s)$; (3) how often the family went on vacation in the past year, without visiting relatives $(0=$ not at all, $1=$ once, $2=$ twice, or $3=$ three times or more); and (4) the number of computers at home. To capture the educational resources in the family, we also included the number of books in the household (Bos et al., 2003). Participants were asked how many books they have at home on a 5 -point Likert scale $(0=$ none or very few to $4=$ more than 200 books). We combined the SES items by performing a principal components analysis and used the factor loadings in our final analyses (see BatistaFoguet, Fortiana, Currie, \& Villalbí, 2004).

\section{Analytic Approach}

We used path analyses in Mplus 7.3 (Muthén \& Muthén, 1998-2012) to investigate the direct and interactive effects of experiences of discrimination and sense of belonging on the socioemotional and academic adjustment of adolescents of immigrant descent. We took the clustered nature of the data with individual students nested in classrooms into account by using the "type is complex" function in MPlus. The final models were estimated with full information maximum likelihood (FIML), which is the recommended practice to effectively make use of all available information while accommodating missing values (Enders, 2010). We began by testing for the main effects of ethnic discrimination, heritage identity, national identity, and belonging with classmates and teachers on socioemotional and academic adjustment (Model 1). We then tested for the interaction effects of discrimination with heritage identity, with classmates' and teachers' belonging. We also explored the interaction effects of discrimination with national identity (Model 2). Whenever we found significant interactions, we performed simple slope analyses to establish the extent to which immigrant descent adolescents' sense of belonging affected the link between discrimination and socioemotional and academic adjustment (Model 3). As recom- mended by Hu and Bentler (1999), we estimated model fit using multiple fit indices (chi-square test of model fit, chisquare, $p>.05$ ), comparative fit index/Tucker-Lewis index (CFI/TLI), root mean square error of approximation (RMSEA), and standardized root mean square residuals (SRMR).

\section{Results}

Table 1 reports the bivariate correlations, descriptive statistics, and reliabilities. The covariates used in the main analyses were age, gender, immigrant generation, heritage groups, and SES. Except for the chi-square test, the final model fit for the rest of the indices was adequate to good for the models, with direct effects of ethnic discrimination as (chi-square $=23.39, p<.001, \mathrm{CFI}=.98$, $\mathrm{TLI}=.86$, RMSEA $=.08$, SRMR $=.05)$ and interaction effects as (chi-square $=8.57, p<.001, \mathrm{CFI}=.97$, TLI $=.92$, RMSEA $=.05$, SRMR $=.04$ ).

The results from Model 1 (direct effects; Table 2) address our first research question of whether higher discrimination and lower heritage identity, national identity, and sense of belonging with classmates and teachers are associated with lower socioemotional and academic adjustment. We found that adolescents who reported higher discrimination also reported greater physiological stress $(\beta=.15, p=.025)$, depressive symptoms $(\beta=.20, p<$ $.001)$, and disruptive school behavior $(\beta=.15, p=.02)$ (supporting hypothesis H1). However, higher discrimination was not associated with lower academic engagement $(\beta=-.03, p=.56)$.

Adolescents who reported higher heritage identity also reported lower physiological stress $(\beta=-.15, p=.031)$, depressive symptoms $(\beta=-.15, p=.006)$, and higher engagement in school $(\beta=.12, p=.034)$. Heritage identity did not relate to disruptive school behavior $(\beta=-.03, p=$ .59) (partially supporting hypothesis H2a). Adolescents who reported greater national identity had greater engagement in school $(\beta=.26, p<.001)$ (partially supporting hypothesis $\mathrm{H} 2 \mathrm{~b}$ ). National identity did not relate to physiological stress $(\beta=-.05, p=.23)$, depressive symptoms $(\beta=-.06, p=.19)$, and disruptive school behavior $(\beta$ $=-.05, p=.29)$. A higher sense of belonging with classmates related to less physiological stress $(\beta=-.28, p$ $<.001)$, depressive symptoms $(\beta=-.43, p<.001)$ and higher engagement in school $(\beta=.15, p=.007)$ but was unrelated to disruptive school behavior $(\beta=-.02, p=.68)$ (partly supporting hypothesis $\mathrm{H} 2 \mathrm{c}$ ). Higher belonging of adolescents with teachers was related to less physiological stress $(\beta=-.22, p<.001)$, depressive symptoms $(\beta=-.32, p$ $<.001)$, disruptive school behavior $(\beta=-.30, p<.001)$, 


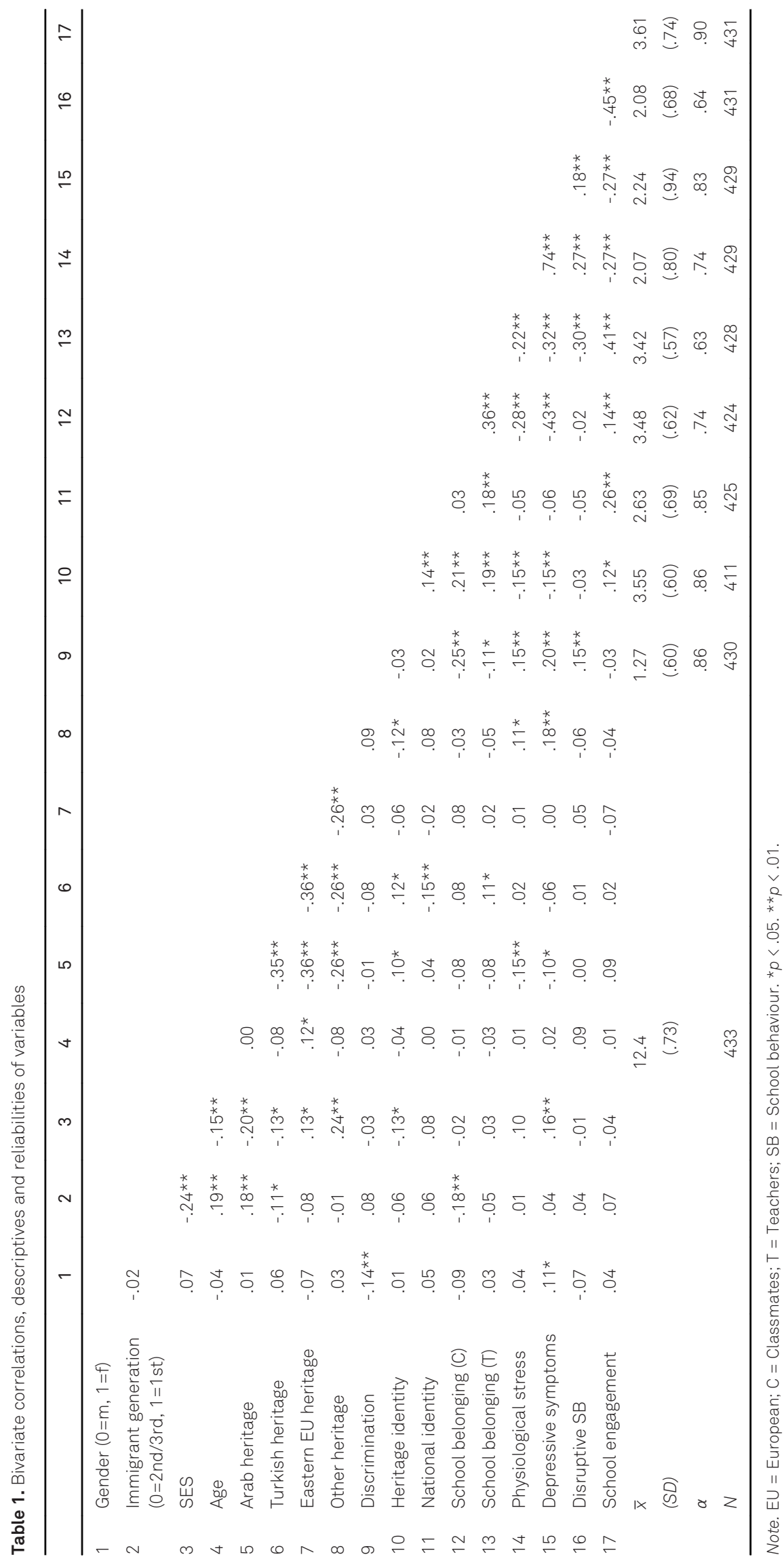




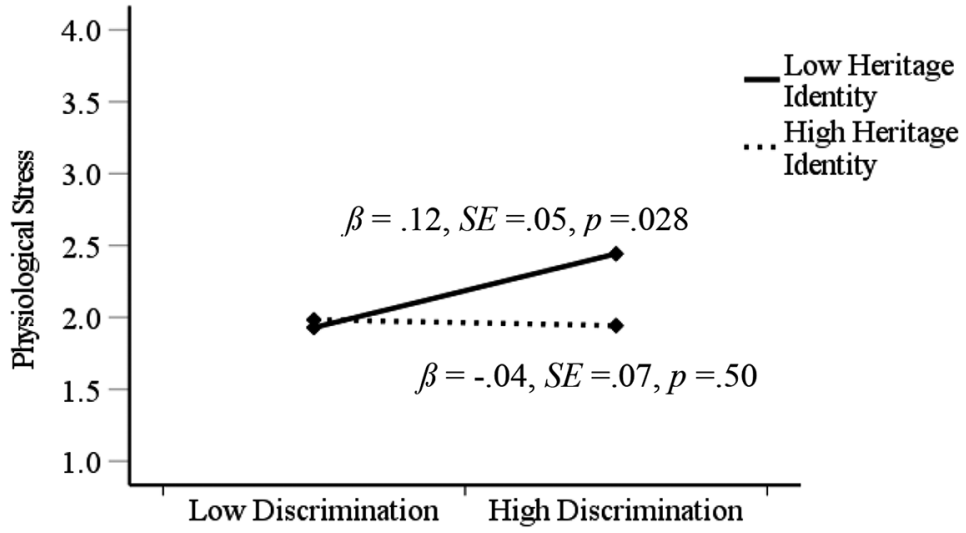

Figure 1. Interaction effects of discrimination (low $=1 S D$ below the mean; high = $1 S D$ above the mean) and heritage identity on physiological stress of adolescents. and greater school engagement $(\beta=.41, p<.001)$ (supporting hypothesis $\mathrm{H} 2 \mathrm{~d}$ ).

Our second research question investigates whether a sense of belonging with these different sources (heritage group, national group, classmates, and teachers) acts as a protective factor weakening the associations of discrimination with adjustment. In hypothesis $\mathrm{H} 3 \mathrm{a}$, as seen in Model 2 (buffering effects; Table 2), we found some interaction effects. Heritage identity buffered the negative association between discrimination and socioemotional and academic adjustment. Adolescents with lower heritage identity - but not those with higher heritage identity - experienced increasing negative adjustment with higher discrimination in terms of physiological stress $(\beta=-.19, p<.001)$, depressive symptoms $(\beta=-.12, p=$ $.021)$, disruptive school behavior $(\beta=-.17, p=.007)$, and academic engagement $(\beta=.20, p<.001)$ (supporting hypothesis H3a). In other words, with increasing discrimination, adolescents with lower heritage identity experienced higher physiological stress and depressive symptoms, but this was not the case for those with higher heritage identity (see Figure 1 and Figure 2). Similarly, with increasing discrimination, adolescents with lower heritage identity exhibited more disruptive behavior in school and engaged less academically, but this was not the case for those with higher heritage identity (see Figure 3 and Figure 4). In our exploratory test for potential buffering effects, however, we did not find any interaction effects with national identity (hypothesis $\mathrm{H} 4$ ).

For belonging with classmates, we did not find any significant interaction effects (not supporting hypothesis
H3b). We did, however, find interaction effects of belonging with teachers and discrimination to physiological stress $(\beta=.18, p=.001)$, but not to depressive symptoms $(\beta=.11, p=.09)$, disruptive school behavior $(\beta=-.01, p=$ $.89)$, and academic engagement $(\beta=-.04, p=.50)$. Yet, in contrast to our hypothesis, there was an increase in physiological stress $(\beta=.18, p<.01)$ with higher discrimination experiences for adolescents with a higher sense of belonging with teachers, but not for those with a lower sense of belonging with teachers (not confirming hypothesis H3c) (see Figure 5). We checked for the robustness of these findings by running the same analysis with a sample of students who speak another language at home other than German with their parents and grandparents. The results were similar to those reported, except for an additional negative interaction effect of belonging with teachers and discrimination on depressive symptoms. ${ }^{5}$

\section{Discussion}

This study not only examined whether higher discrimination and lower sense of belonging with classmates, teachers, heritage group, and national group are associated with lower socioemotional and academic adjustment of adolescents of immigrant descent in Germany, but also sought to establish whether a sense of belonging with these different sources (classmates, teachers, heritage group and national group) acts as a protective factor weakening the link between discrimination and adjust-

\footnotetext{
We sampled students who speak another language at home with their parents and grandparents $(N=367)$ and ran similar analyses. The findings were largely consistent with the reported results. We did not find differing effects for direct associations. Consistent with reported findings, we found interaction effects of heritage identity and discrimination on physiological stress $(\beta=-.19, p<.01)$, depressive symptoms ( $\beta$ $=-.12, p<.05)$, disruptive school behavior $(\beta=-.18, p<.01)$, and school engagement $(\beta=.19, p<.01)$. For belonging with teachers and discrimination, however, we found an additional result. Besides the similar interaction effects on physiological stress $(\beta=.22, p<.001)$, adolescents in addition showed higher depressive symptoms $(\beta=.13, p<.05)$.
} 
Table 2. Path analyses coefficients for direct and interactive relations of discrimination and heritage identity, national identity, belonging with classmates and belonging with teachers

\begin{tabular}{|c|c|c|c|c|c|c|}
\hline & \multicolumn{2}{|c|}{ Model 1} & \multicolumn{2}{|c|}{ Model 2} & \multicolumn{2}{|c|}{ Model 3} \\
\hline & $\beta$ & S.E & $\beta$ & S.E & $\beta$ & S.E \\
\hline \multicolumn{7}{|l|}{ Physiological stress } \\
\hline Discrimination & $.15^{\star}$ & .06 & .05 & .08 & & \\
\hline Heritage identity & $-.15^{\star}$ & .06 & -.01 & .06 & & \\
\hline National identity & -.05 & .05 & -.01 & .05 & & \\
\hline Belonging (C) & $-.28 * \star \star$ & .05 & $-.25^{\star \star \star}$ & .06 & & \\
\hline Belonging $(T)$ & $-.22 * \star \star$ & .05 & $-.14^{\star}$ & .06 & & \\
\hline Discrimination $x$ Heritage identity & & & $-.19 * \star \star$ & .05 & & \\
\hline Discrimination x National identity & & & .01 & .21 & & \\
\hline Discrimination x Belonging (C) & & & -.03 & .06 & & \\
\hline Discrimination x Belonging $(T)$ & & & $.18^{\star \star}$ & .06 & & \\
\hline Discrimination $\times$ Heritage identity $(\mathrm{H})$ & & & & & -.04 & .07 \\
\hline Discrimination $x$ Heritage identity $(\mathrm{L})$ & & & & & $.12 *$ & .05 \\
\hline Discrimination x Belonging $(\mathrm{T})(\mathrm{H})$ & & & & & $.16^{\star}$ & .07 \\
\hline Discrimination x Belonging $(\mathrm{T})(\mathrm{L})$ & & & & & -.10 & .07 \\
\hline \multicolumn{7}{|l|}{ Depressive symptoms } \\
\hline Discrimination & $.20 * \star \star$ & .06 & $.11^{x}$ & .07 & & \\
\hline Heritage identity & $-.15^{\star \star}$ & .05 & .01 & .04 & & \\
\hline National identity & -.06 & .05 & -.02 & .05 & & \\
\hline Belonging (C) & $-.43 * \star \star$ & .04 & $-.33 * \star \star$ & .06 & & \\
\hline Belonging $(T)$ & 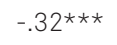 & .05 & $-.17 \star \star$ & .05 & & \\
\hline Discrimination $x$ Heritage identity & & & $-.12^{\star}$ & .05 & & \\
\hline Discrimination $\times$ National identity & & & -.02 & .05 & & \\
\hline Discrimination x Belonging (C) & & & -.01 & .06 & & \\
\hline Discrimination x Belonging $(T)$ & & & .11 & .06 & & \\
\hline Discrimination x Heritage $(\mathrm{H})$ & & & & & .04 & .06 \\
\hline Discrimination x Heritage $(\mathrm{L})$ & & & & & $.10^{\infty}$ & .07 \\
\hline \multicolumn{7}{|l|}{ Disruptive Sch behaviour } \\
\hline Discrimination & $.15^{\star}$ & .07 & .06 & .08 & & \\
\hline Heritage identity & -.03 & .05 & -.01 & .06 & & \\
\hline National identity & -.05 & .05 & -.02 & .06 & & \\
\hline Belonging (C) & -.02 & .05 & $.12^{\star}$ & .07 & & \\
\hline Belonging $(T)$ & $-.30 * \star \star$ & .05 & $-.33 * \star \star$ & .05 & & \\
\hline Discrimination $x$ Heritage identity & & & $-.17 * \star$ & .06 & & \\
\hline Discrimination $\times$ National identity & & & .04 & .10 & & \\
\hline Discrimination x Belonging (C) & & & -.03 & .06 & & \\
\hline Discrimination x Belonging $(T)$ & & & -.01 & .08 & & \\
\hline Discrimination x Heritage $(\mathrm{H})$ & & & & & $.09 *$ & .04 \\
\hline Discrimination $x$ Heritage $(L)$ & & & & & $.12 * \star$ & .04 \\
\hline \multicolumn{7}{|l|}{ School Engagement } \\
\hline Discrimination & -.03 & .05 & $.13^{\star}$ & .06 & & \\
\hline Heritage identity & $.12^{\star}$ & .05 & .03 & .06 & & \\
\hline National identity & $.26 * \star \star$ & .05 & $.19 * \star \star$ & .05 & & \\
\hline Belonging (C) & $.15^{\star \star}$ & .05 & .07 & .05 & & \\
\hline Belonging $(\mathrm{T})$ & $.41 * \star \star$ & .03 & $.35^{\star \star *}$ & .05 & & \\
\hline Discrimination $x$ Heritage identity & & & $.20 * \star \star$ & .05 & & \\
\hline Discrimination $\times$ National identity & & & .01 & .05 & & \\
\hline Discrimination x Belonging (C) & & & .03 & .05 & & \\
\hline
\end{tabular}


Table 2. Path analyses coefficients for direct and interactive relations of discrimination and heritage identity, national identity, belonging with classmates and belonging with teachers (Continued)

\begin{tabular}{|c|c|c|c|c|c|c|}
\hline & \multicolumn{2}{|c|}{ Model 1} & \multicolumn{2}{|c|}{ Model 2} & \multicolumn{2}{|c|}{ Model 3} \\
\hline & $\beta$ & S.E & $\beta$ & S.E & $\beta$ & S.E \\
\hline Discrimination x Belonging $(\mathrm{T})$ & & & -.02 & .05 & & \\
\hline Discrimination $\times$ Heritage $(H)$ & & & & & .08 & .06 \\
\hline Discrimination $x$ Heritage $(L)$ & & & & & $-.16 * \star \star$ & .04 \\
\hline
\end{tabular}

Note. H=High; L=Low; Sch=School; C=Classmates; T=Teachers; ${ }^{\star} p<.1 .{ }^{\star} p<.05 .{ }^{* \star} p<.01 .{ }^{\star \star \star} p<.001$
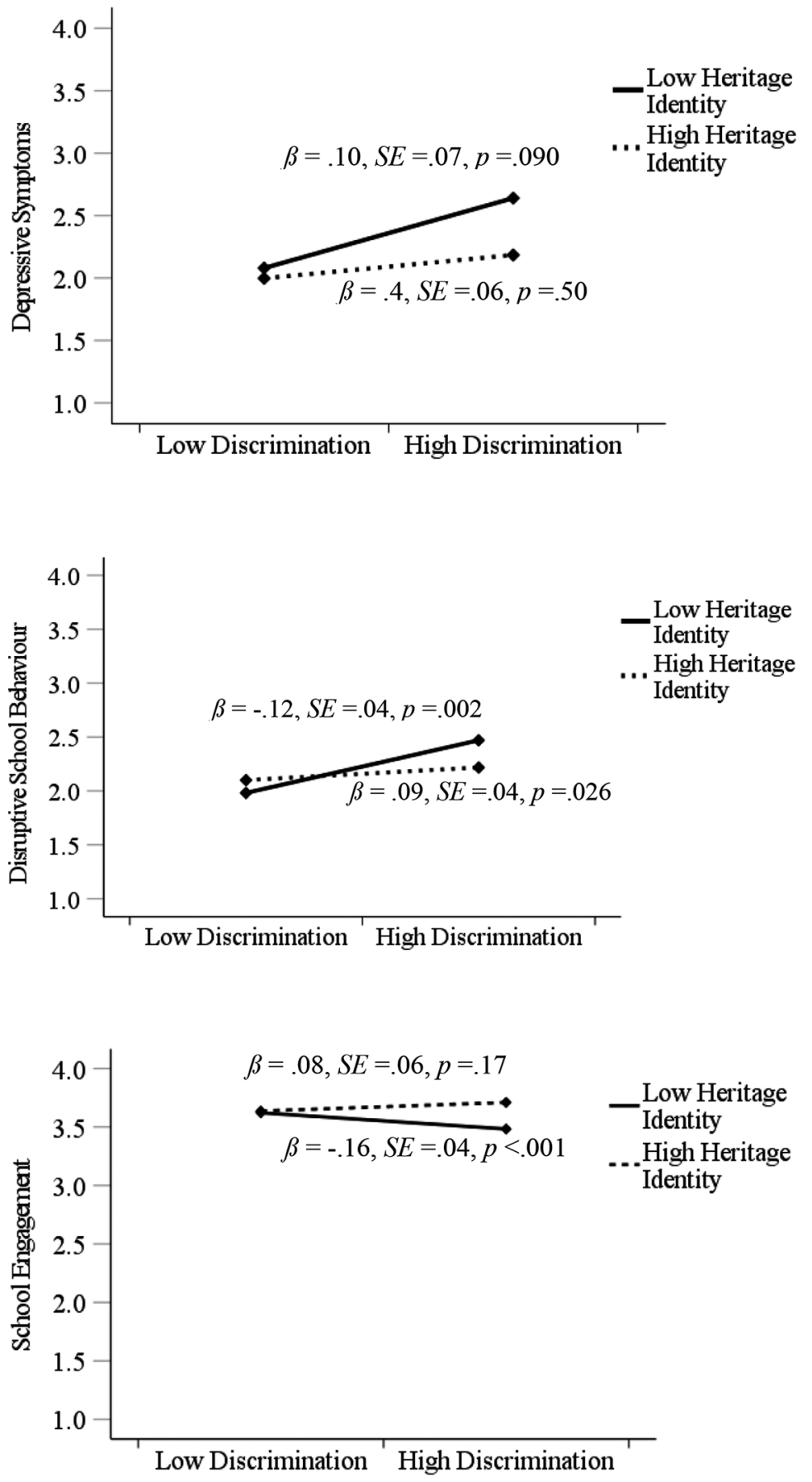

Figure 2. Interaction effects of discrimination (Low $=1 \mathrm{SD}$ below the mean; High = 1SD above the mean) and heritage identity on adolescents' depressive symptoms.

Figure 3. Interaction effects of discrimination (low $=1 S D$ below the mean; high = $1 S D$ above the mean) and heritage identity on disruptive school behavior of adolescents.
Figure 4. Interaction effects of discrimination (low $=1 S D$ below the mean; high = $1 S D$ above the mean) and heritage identity on school engagement of adolescents. 


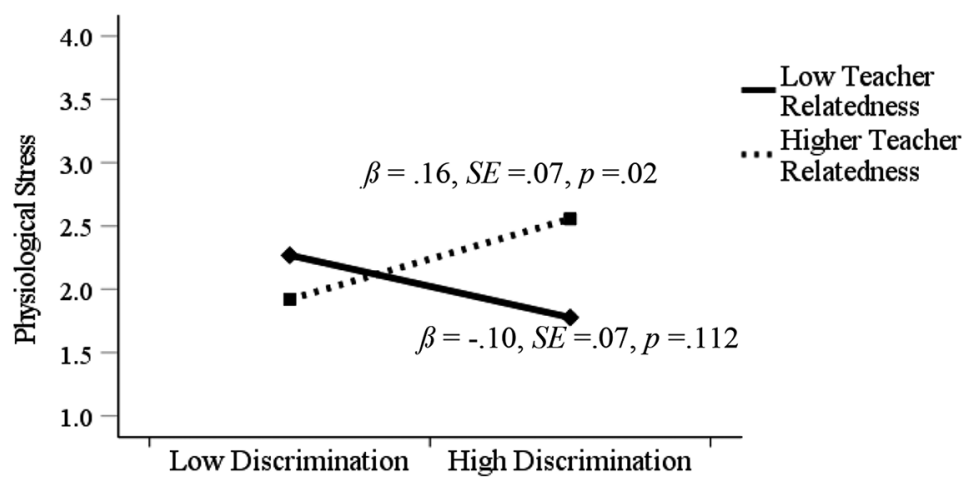

Figure 5. Interaction effects of discrimination (low $=1 S D$ below the mean; high = $1 S D$ above the mean) and teacher relatedness on physiological stress of adolescents.

ment. Our findings reveal that, when adolescents of immigrant descent in Germany experience discrimination, a higher heritage identity can be a protective factor. We also found that with more discrimination, a higher sense of belonging with teachers is linked to physiological stress among this group of adolescents.

In investigating the direct effects, we found that more ethnic discrimination was linked to greater physiological stress, depressive symptoms, and disruptive school behavior among adolescents. In contrast, discrimination was not related to school engagement. These findings are largely consistent with previous research on the negative effects of discrimination on adjustment of adolescents (Aichberger et al., 2015; Benner et al., 2018) and confirm that adolescents of immigrant descent in Germany experience ethnic discrimination, adversely correlating with their socioemotional adjustment. Most youth in our sample attended schools where most students were of immigrant descent. One would expect that such schools, located in largely diverse neighborhoods, would enhance adaptation and inclusion of these youth in their schools and their communities, which would in return enhance their well-being (Frankenberg et al., 2013; Schachner et al., 2014). However, ethnic discrimination continues to be a social barrier to this process. Perhaps as much as they strive to adjust and be included, peers undermine this effort by failing to accept their peers of immigrant descent. As a result, and because of a lack of support and needed intervention, adolescents of immigrant descent may cope poorly with discrimination-related stress and react negatively by displaying disruptive behavior in school (Aichberger et al., 2015; Stein et al., 2015).

We also found that adolescents of immigrant descent with higher heritage identity reported fewer physiological stress and depressive symptoms as well as higher school engagement. Heritage identity was not related to disruptive school behavior. Our findings are generally consistent with previous studies showing the potential benefits of maintaining a close connection to one's heritage group (e.g., Rivas-Drake et al., 2014; Yip et al., 2019). Feeling valued as a member of one's heritage group and having clarity about the role and meaning of heritage identity in their lives can help adolescents to have a better sense of who they are overall, hence contributing to positive adjustment (Rivas-Drake et al., 2014; Umaña-Taylor et al., 2014). Furthermore, by having higher self-esteem and greater well-being as a result, adolescents have the advantage of being able to positively navigate the social space outside their home. They participate more actively and confidently in school and in the community when aware that they are important members of the school and the community they live in (Booker, 2004; Goodenow \& Grady, 1993).

National identity was related to greater school engagement for immigrant descent adolescents, like what other studies have found (Berry et al., 2006; Göbel \& Preusche, 2019; Schotte et al., 2018). However, national identity was unrelated to physiological stress, depressive symptoms, and disruptive school behavior, like other studies whose findings were inconclusive on its direct association with more general psychological well-being (Göbel \& Preusche, 2019; Schachner et al., 2016; Schotte et al., 2018). A stronger national identity may be a proxy for greater ease in navigating the majority culture, which is advantageous for meeting the academic demands of the school context. But it could also mean that having a higher national identity enhances immigrant descent adolescents' perception of equal opportunities with the majority group in school.

Importantly, beyond direct effects, we found that belonging to a heritage group is a protective factor for adolescents of immigrant descent in Germany. Specifically, heritage identity attenuated the negative effects of ethnic discrimination experiences on socioemotional and academic adjustment of adolescents. The findings confirmed our hypothesis and were consistent with prior research in contexts other than Germany, which suggested that adolescents with a stronger heritage identity were 
less likely to be negatively affected by discrimination from their classmates (e.g., Greene et al., 2006; Yip et al., 2019). These findings further underscore the fact that adolescents of immigrant descent adjust positively to environments that cultivate ties to their heritage culture. Our study was conducted in the culturally diverse city of Berlin. In this context, adolescents of immigrant descent may be more likely to be surrounded by people who can share similar experiences, including how best to cope with discrimination. It could also mean that they feel a part of a valued community, from which they draw both cognitive and emotional security (Erikson, 1968; Yip et al., 2019). Processes contributing to understanding the importance of heritage ties among the youth and enhance such identification should be harnessed more as resources and coping mechanisms in light of facing experiences of being devalued. Our study thus contributes new evidence about the protective role of heritage identity among adolescents of immigrant descent in Germany.

We found that national identity did not act as a protective factor for adolescents of immigrant descent in Germany. According to identity-denial research, experiencing discrimination or feelings of exclusion can be more hurtful for adolescents living in a country they highly identify with than for adolescents who do not highly identify with that country (Wang et al., 2012). Thus, the potential protective effects of feeling part of a valued community (i.e., feeling "German") may be erased. Alternatively, another study found that national identity did not protect against negative effects of discrimination unless it was combined with a strong heritage identity (Huynh et al., 2014). Future studies could look more closely into such combinations or profiles of protective factors, since a body of literature shows the potential benefits of identifying with not just one, but multiple cultures (e.g., Nguyen \& Benet-Martínez, 2013).

Our findings on belonging with classmates and with teachers were in line with previous research suggesting negative relations with physiological stress, depressive symptoms, and positive relations with school engagement (Kiang et al., 2011; Golaszewski et al., 2018; Slaten et al., 2016). The results confirm that both classmate and teacher support is relevant to fostering school engagement and better health among adolescents of immigrant descent (Göbel \& Preusche, 2019). Therefore, the quality of the support students receive from their classmates and teachers is highly relevant to how they feel involved with their school and with their learning (Libbey, 2004). The quality of support could also be influenced by the level of trust between students and between students and teachers. Adolescents seek help from their teachers and their peers when they feel secure around them. There is, hence, the need for students and teachers to be aware and to strive to ensure a caring and inclusive school climate (Ryan \& Deci, 2017) that fosters productive engagement and positive coping with daily stressors in school (Kelly et al., 2018).

Finally, a sense of belonging with classmates and with teachers did not act as a protective factor. Contrary to our hypothesis, adolescents with a higher sense of belonging with teachers reported increasing physiological stress when exposed to higher discrimination in comparison to those with a lower sense of belonging with teachers. These findings resemble those of Brenick and colleagues (2018) in their study on cross-ethnic friendships with majority peers in Germany. Since teachers represent the cultural majority in Germany, ethnic discrimination could as well be a source of distress in belonging with teachers. This may again depend on whether teachers respond to adolescents' discrimination experiences by either acknowledging it, intervening, or doing nothing about it. However, the lack of teacher support, when expected by these adolescents (i.e., perhaps their failure to acknowledge and intervene when these students experience discrimination) may worsen the effects of their discrimination experience. An alternate interpretation to this finding may be that adolescents experiencing more discrimination from their classmates and who are the most affected tend to seek support from their teachers, and in the process, they end up creating close ties with teachers.

\section{Implications, Limitations, and Future Directions}

Our study contributes to the literature on experiences of adolescent discrimination and adjustment in three ways. First, we address the gap highlighted in a recent metaanalysis that most studies still focus on U.S. youth. Discrimination is an everyday part of life for adolescents around the world (Berry et al., 2006), so that more studies from outside the U.S. are needed. Second, we examined how a sense of belonging acts not only as a promotive factor for socioemotional and academic adjustment of adolescents of immigrant descent, but also as a potential protective factor in the face of discrimination. Third, because a sense of belonging has been conceptualized across diverse literatures, we included two means of belonging that have not yet been considered together: a sense of belonging to one's cultural group as well as to the proximal school context. A focus on protective factors is needed for enhancing prevention and intervention efforts 
to reduce the negative effects of discrimination when it happens.

Even though the present study provides important insights and highlights a sense of belonging as a fundamental need (Baumeister \& Leary, 1995), the findings of negative interaction effects of belonging with teachers should be interpreted with caution in light of this study's limitation of using cross-sectional data. Our use of crosssectional data limited us to testing nondirectional effects. As such, future longitudinal investigation would provide important insights.

Research is needed with a broader perspective into why adolescents' stronger sense of belonging with their teachers may exacerbate the effects of discrimination experiences in Germany. Moreover, more research is needed concerning the protective role of cultural belonging in Germany to pave the way for the development of interventions with long-term effects. Similar analyses with a sample composed of adolescents who speak a language other than German at home with their parents and grandparents yielded an additional finding: interaction effects of belonging with teachers and discrimination increased depressive symptoms. So, future studies should incorporate as well a broad range of operationalizations of immigrant descent.

\section{Concluding Remarks}

Different lines of literature highlighted a sense of belonging as a fundamental need (Baumeister \& Leary, 1995; Ryan \& Deci, 2017) and a key promotive and protective process, especially for ethnic minorities and in the light of perceived discrimination or stereotype threat (e.g., Shnabel et al., 2013; Walton \& Cohen, 2007; Yip et al., 2019, Zimmerman et al., 2013). Yet, our study shows that it is important to understand the exact source of belonging in any given context, as findings may diverge. Findings of the potentially protective role of heritage identity in Germany suggest that providing opportunities in schools and communities to maintain ties to one's heritage culture is important. This may be an important resource to highlight in the training and development of teachers and those working with youth of diverse communities.

In addition, it is crucial to better understand the role of the social context in shaping the effects of belonging. A positive intergroup climate in the classroom has been identified as one condition preventing discriminationexacerbating effects of minority-majority relations (Brenick et al., 2018). Therefore, investing in a more supportive intergroup and multicultural climate at the classroom, school, and national levels may be beneficial.

\section{References}

Aichberger, M., Bromand, Z., Rapp, M., Yesil, R., Montesinos, A., Temur-Erman, S., Heinz, A., \& Schouler-Ocak, M. (2015). Perceived ethnic discrimination, acculturation, and psychological distress in women of Turkish origin in Germany. Social Psychiatry and Psychiatric Epidemiology, 50(11), 1691-1700. https://doi.org/10.1007/s00127-015-1105-3

Bakadorova, O., \& Raufelder, D. (2014). The mediating role of socio-motivational support in the association between individual school self-concept and achievement motivation amongst adolescent students. European Journal of Psychology of Education, 29(3), 347-366. https://doi.org/10.1007/s10212-0130202-5

Batista-Foguet, J., Fortiana, J., Currie, C., \& Villalbí, J. (2004). Socio-economic indexes in surveys for comparisons between countries. Social Indicators Research, 67(3), 315-332. https:// doi.org/10.1023/b:soci.0000032341.14612.b8

Baumeister, R. F., \& Leary, M. R. (1995). The need to belong: Desire for interpersonal attachments as a fundamental human motivation.Psychological Bulletin, 11, 497 -529. https://doi.org/10. 1037/0033-2909.117.3.497

Benner, A., \& Wang, Y. (2017). Racial/ethnic discrimination and adolescents' well-being: The role of cross-ethnic friendships and friends' experiences of discrimination. Child Development, 88(2), 493 - 504. https://doi.org/10.1111/cdev.12606

Benner, A., Wang, Y., Shen, Y., Boyle, A., Polk, R., \& Cheng, Y. (2018). Racial/ethnic discrimination and well-being during adolescence: A meta-analytic review. American Psychologist, 73(7), 855 - 883. httsp://doi.org/10.1037/amp0000204

Berry, J., Phinney, J., Sam, D., \& Vedder, P. (2006). Immigrant youth: Acculturation, identity, and adaptation. Applied Psychology, 55(3), 303-332. httsp://doi.org/10.1111/j.1464-0597. 2006.00256.x

Booker, K. (2004). Exploring school belonging and academic achievement in African American adolescents. Curriculum and Teaching Dialogue, 6(2), $131-143$.

Bos, W., Lankes, E.-M., Prenzel, M., Schwippert, K., Walther, G., \& Valtin, R. (Eds.). (2003). Schülerleistungen am Ende der vierten Jahrgangsstufe im internationalen Vergleich [Student performance at the end of the fourth grade in international comparison]. Waxmann.

Boyce, W., Torsheim, T., Currie, C., \& Zambon, A. (2006). The family affluence scale as a measure of national wealth: Validation of an adolescent self-report measure. Social Indicators Research, 78(3), 473-487. https://doi.org/10.1007/s11205-005-1607-6

Branscombe, N. R., Schmitt, M. T., \& Harvey, R. D. (1999). Perceiving pervasive discrimination among African Americans: Implications for group identification and well-being. Journal of Personality and Social Psychology, 77, 135-149. https://doi. org/10.1037/0022-3514.77.1.135

Brenick, A., Schachner, M., \& Jugert, P. (2018). Help or hindrance? Minority versus majority cross-ethnic friendships altering discrimination experiences. Journal of Applied Developmental Psychology, 59, 26 -35. https://doi.org/10.1016/j.appdev.2018. 04.006

Bundesamt für Migration und Flüchtlinge. (2018). Annual report on migration monitoring - 2018. Retrieved from https://www.bamf. de/SharedDocs/Anlagen/DE/Forschung/BerichtsreihenMigra tionIntegration/Wanderungsmonitoring/wanderungsmonitor ing-jahresbericht-2018.pdf?__blob=publicationFile\&v=16

Deci, E. L., \& Ryan, R. M. (2014). The importance of universal psychological needs for understanding motivation in the workplace. In M. Gagné (Ed.), Oxford handbook of work engagement, 
motivation, and self-determination theory (pp. 13-32). Oxford University Press.

Enders, C. (2010). Applied missing data analysis. Guilford.

Erikson, E. (1968). Identity: Youth and crisis. Norton.

Federal Government Expert Commission. (2021). Shaping our immigration society together: Federal Government Expert Commission on the framework for sustainable integration. Retrieved from https://www.xn-fachkommission-integrationsfhigkeitx7c.de/fk-int/dokumente

Fernandez, A., Loukas, A., Golaszewski, N., Batanova, M., \& Pasch, K. (2019). Adolescent adjustment problems mediate the association between racial discrimination and school connectedness. Journal of School Health, 89(12), 945-952. https://doi. org/10.1111/josh.12838

Frankenberg, E., Kupper, K., Wagner, R., \& Bongard, S. (2013). Immigrant youth in Germany: Psychological and sociological adaptation. European Psychologist, 18(3), 158-168. https:// doi.org/10.1027/1016-9040/a000154

Furrer, C., \& Skinner, E. (2003). Sense of relatedness as a factor in children's academic engagement and performance. Journal of Educational Psychology, 95(1), 148-162. https://doi.org/10. 1037/0022-0663.95.1.148

Garrett, B., Livingston, B., Livingston, M., \& Komro, K. (2017). The effects of perceived racial/ethnic discrimination on substance use among youths living in the Cherokee Nation. Journal of Child \& Adolescent Substance Abuse, 26(3), 242-249. https://doi. org/10.1080/1067828x.2017.1299656

Göbel, K., \& Preusche, Z. (2019). Emotional school engagement among minority youth: the relevance of cultural identity, perceived discrimination, and perceived support. Intercultural Education, 30(5), 547-563. https://doi.org/10.1080/14675986. 2019.1616263

Golaszewski, N., Pasch, K., Fernandez, A., Poulos, N., Batanova, M., \& Loukas, A. (2018). Perceived weight discrimination and school connectedness among youth: Does teacher support play a protective role? Journal of School Health, 88(10), 754-761. https://doi.org/10.1111/josh.12682

Goodenow, C., \& Grady, K. (1993). The relationship of school belonging and friends' values to academic motivation among urban adolescent students. The Journal of Experimental Education, 62(1), 60-71. https://doi.org/10.1080/00220973.1993. 9943831

Greene, M., Way, N., \& Pahl, K. (2006). Trajectories of perceived adult and peer discrimination among Black, Latino, and Asian American adolescents: Patterns and psychological correlates. Developmental Psychology, 42(2), 218 -236. https://doi.org/10. 1037/0012-1649.42.2.218

Hu, L., \& Bentler, P. (1999). Cutoff criteria for fit indexes in covariance structure analysis: Conventional criteria versus new alternatives. Structural Equation Modeling: A Multidisciplinary Journal, 6(1), 1-55. https://doi.org/10.1080/107055199 09540118

Huynh, Q.-L., Devos, T., \& Goldberg, R. (2014). The role of ethnic and national identifications in perceived discrimination for Asian Americans: Toward a better understanding of the buffering effect of group identifications on psychological distress. Asian American Journal of Psychology, 5(3), 161-171. https:// doi.org/10.1037/a0031601

Jasinskaja-Lahti, I., Liebkind, K., Horenczyk, G., \& Schmitz, P. (2003). The interactive nature of acculturation: perceived discrimination, acculturation attitudes and stress among young ethnic repatriates in Finland, Israel and Germany. International Journal of Intercultural Relations, 27(1), 79 -97. https://doi.org/ 10.1016/s0147-1767(02)00061-5
Jenkins, P. (1995). School delinquency and school commitment. Sociology of Education, 68(3), 221. https://doi.org/10.2307/ 2112686

Juang, L., Simpson, J., Lee, R., Rothman, A., Titzmann, P., \& Schachner, M. et al. (2018). Using attachment and relational perspectives to understand adaptation and resilience among immigrant and refugee youth. American Psychologist, 73(6), 797 -811. https:/doi.org/10.1037/amp0000286

Kelly, A., Vella-Brodrick, D., \& Waters, L. (2018). Rethinking school belonging: A socio-ecological framework. In Allen, K., \& Boyle, C. (Eds.), Pathways to belonging: Contemporary perspectives of school belonging (p.191 - 218). Brill.

Kiang, L., Supple, A., Stein, G., \& Gonzalez, L. (2011). Gendered academic adjustment among Asian American adolescents in an emerging immigrant community. Journal of Youth and Adolescence, 41(3), 283-294. https://doi.org/10.1007/s10964-0119697-8

Korpershoek, H., Canrinus, E., Fokkens-Bruinsma, M., \& de Boer, H. (2019). The relationships between school belonging and students' motivational, social-emotional, behavioural, and academic outcomes in secondary education: a meta-analytic review. Research Papers in Education, 35(6), 641 -680. https:// doi.org/10.1080/02671522.2019.1615116

Leszczensky, L., \& Gräbs Santiago, A. (2014). Die Messung ethnischer und nationaler Identität von Kindern und Jugendlichen [The measurement of ethnic and national identity of children and adolescents]. Mannheimer Zentrum für Europäische Sozialforschung.

Libbey, H. (2004). Measuring student relationships to school: Attachment, bonding, connectedness, and engagement. Journal of School Health, 74(7), $274-283$. https://doi.org/10.1111/j. 1746-1561.2004.tb08284.x

Loukas, A., Ripperger-Suhler, K., \& Horton, K. (2008). Examining temporal associations between school connectedness and early adolescent adjustment. Journal of Youth and Adolescence, 38(6), 804-812. https://doi.org/10.1007/s10964-008-9312-9

Maes, M., Stevens, G., \& Verkuyten, M. (2014). Perceived ethnic discrimination and problem behaviors in Muslim immigrant early adolescents. The Journal of Early Adolescence, 34(7), 940 - 966. https://doi.org/10.1177/0272431613514629

Muthén, L., \& Muthén, B. (1998-2012). Mplus user's guide (7th ed.). Author.

Nguyen, A., \& Benet-Martínez, V. (2013). Biculturalism and adjustment. Journal of Cross-Cultural Psychology, 44(1), 122-159. https://doi.org/10.1177/0022022111435097

Phinney, J. (1996). When we talk about American ethnic groups, what do we mean? American Psychologist, 51(9), 918-927. https://doi.org/10.1037/0003-066x.51.9.918

Quintana, S. (2008). Racial perspective taking ability: Developmental, theoretical, and empirical trends. In S.M. Quintana \& C. McKown (Eds.), Handbook of race, racism, and the developing child (p. 16-36). Wiley. https://doi.org/10.1002/ 9781118269930

Reitz, A., Asendorpf, J., \& Motti-Stefanidi, F. (2015). When do immigrant adolescents feel personally discriminated against? Longitudinal effects of peer preference. International Journal of Behavioral Development, 39(3), 197 -209. https://doi.org/10. 1177/0165025414567008

Richter, M., \& Leppin, A. (2007). Trends in socio-economic differences in tobacco smoking among German schoolchildren, 1994 2002. The European Journal of Public Health, 17(6), 565-571. https://doi.org/10.1093/eurpub/ckm010

Rivas-Drake, D., Syed, M., Umaña-Taylor, A., Markstrom, C., French, S., Schwartz, S., \& Lee, R. (2014). Feeling good, happy, and proud: A meta-analysis of positive ethnic-racial affect and 
adjustment. Child Development, 85(1), 77 - 102. https://doi.org/ 10.1111/cdev.12175

Ryan, R., \& Deci, E. (2017). Self-determination theory. Guilford.

Schachner, M., Noack, P., Van de Vijver, F., \& Eckstein, K. (2016). Cultural diversity climate and psychological adjustment at school-equality and inclusion versus cultural pluralism. Child Development, 87(4), 1175-1191. https://doi.org/10.1111/cdev. 12536

Schachner, M., Schwarzenthal, M., Van de Vijver, F., \& Noack, P. (2019). How all students can belong and achieve: Effects of the cultural diversity climate amongst students of immigrant and nonimmigrant background in Germany. Journal of Educational Psychology, 111(4), 703-716. https://doi.org/10.1037/edu000 0303

Schachner, M., Van de Vijver, F., \& Noack, P. (2014). Family-related antecedents of early adolescent immigrants' psychological and sociocultural school adjustment in Germany. Journal of CrossCultural Psychology, 45(10), 1606-1625. https://doi.org/10. 1177/0022022114543831

Schotte, K., Stanat, P., \& Edele, A. (2018). Is integration always most adaptive? The role of cultural identity in academic achievement and in psychological adaptation of immigrant students in Germany. Journal of Youth and Adolescence, 47(1), 16 - 37. https://doi.org/10.1007/s10964-017-0737-x

Shnabel, N., Purdie-Vaughns, V., Cook, J., Garcia, J., \& Cohen, G. (2013). Demystifying values-affirmation interventions. Personality and Social Psychology Bulletin, 39(5), 663-676. https:// doi.org/10.1177/0146167213480816

Skinner, E., Kindermann, T., \& Furrer, C. (2009). A motivational perspective on engagement and disaffection. Educational and Psychological Measurement, 69(3), 493-525. https://doi.org/ $10.1177 / 0013164408323233$

Slaten, C., Ferguson, J., Allen, K., Brodrick, D., \& Waters, L. (2016). School belonging: A review of the history, current trends, and future directions. The Educational and Developmental Psychologist, 33(1), 1 - 15. https://doi.org/10.1017/edp.2016.6

Stein, G., Supple, A., Huq, N., Dunbar, A., \& Prinstein, M. (2015). A longitudinal examination of perceived discrimination and depressive symptoms in ethnic minority youth: The roles of attributional style, positive ethnic/racial affect, and emotional reactivity. Developmental Psychology, 52(2), 259-271. https:// doi.org/10.1037/a0039902

Suarez-Orozco, C., Pimentel, A., \& Martin, M. (2009). The significance of relationships: Academic engagement and achievement among newcomer immigrant youth. Teachers College Record, 111(3), $712-749$.

Tajfel, H., \& Turner, J. C. (1979). An integrative theory of intergroup conflict. In W. G. Austin \& S. Worchel (Eds.), The social psychology of intergroup relations (pp. 56-65). Brooks/Cole.

Titzmann, P., Silbereisen, R., Mesch, G., \& Schmitt-Rodermund, E. (2011). Migration-specific hassles among adolescent immigrants from the former Soviet Union in Germany and Israel. Journal of Cross-Cultural Psychology, 42(5), 777 - 794. https:// doi.org/10.1177/0022022110362756

Umaña-Taylor, A., Quintana, S., Lee, R., Cross, W., Rivas-Drake, D., Schwartz, S., Syed, M., Yip, T., \& Seaton, E. (2014). Ethnic and racial identity during adolescence and into young adulthood: An integrated conceptualization. Child Development, 85(1), 21 - 39. https://doi.org/10.1111/cdev.12196
Verkuyten, M., \& Thijs, J. (2002). Racist victimization among children in The Netherlands: The effect of ethnic group and school. Ethnic and Racial Studies, 25(2), 310 -331. https://doi. org/10.1080/01419870120109502

Verkuyten, M., Thijs, J., \& Gharaei, N. (2019). Discrimination and academic (dis)engagement of ethnic-racial minority students: a social identity threat perspective. Social Psychology of Education, 22(2), 267-290. https://doi.org/10.1007/s11218-01809476-0

Vietze, J., Juang, L., \& Schachner, M. (2019). Peer cultural socialisation: a resource for minority students' cultural identity, life satisfaction, and school values. Intercultural Education, 30(5), 579 - 598. https://doi.org/10.1080/14675986.2019.1586213

Walton, G., \& Cohen, G. (2007). A question of belonging: Race, social fit, and achievement. Journal of Personality and Social Psychology, 92(1), 82-96. https://doi.org/10.1037/0022-3514. 92.1.82

Wang, J., Minervino, C., \& Cheryan, S. (2012). Generational differences in vulnerability to identity denial: The role of group identification. Group Processes \& Intergroup Relations, 16(5), $600-617$. https://doi.org/10.1177/1368430212461963

Yip, T., Wang, Y., Mootoo, C., \& Mirpuri, S. (2019). Moderating the association between discrimination and adjustment: A metaanalysis of ethnic/racial identity. Developmental Psychology, 55(6), $1274-1298$. https://doi.org/10.1037/dev0000708

Zimmerman, M., Stoddard, S., Eisman, A., Caldwell, C., Aiyer, S., \& Miller, A. (2013). Adolescent resilience: Promotive factors that inform prevention. Child Development Perspectives, 7(4), $215-$ 220. https://doi.org/10.1111/cdep.12042

\section{Acknowledgment}

This research was funded by a research grant from the German Research Foundation (DFG), grant no. 335746752 (applicant: Prof. Dr. Linda Juang, coapplicant: Prof. Dr. Maja Schachner).

\section{Funding}

Open access publication enabled by University of Potsdam.

\section{ORCID}

David Kunyu

(D) https://orcid.org/0000-0003-1710-2049

Linda P. Juang

(iD https://orcid.org/0000-0002-0308-6378

Maja K. Schachner

(iD) https://orcid.org/0000-0002-9388-7485

Miriam Schwarzenthal

(iD) https://orcid.org/0000-0002-6278-6227

\section{David Kunyu}

Department of Inclusive Education

University of Potsdam

Karl-Liebknecht-Straße 24-25

14476 Potsdam

Germany

kunyu@uni-potsdam.de 